\title{
"Peripheral" Astronomy in the Correspondence of Johannes Hevelius: A Case Study of Maria Cunitia and Elias von Löwen
}

The letters of Johannes Hevelius reveal a very interesting map of the European astronomy of the $17^{\text {th }}$ century. Significantly, Hevelius was not only a key agent in the transmission of scientific information among the main centres which, for example, made Gdańsk equally important as London and Paris for early modern uranography. Hevelius also exchanged letters with astronomers whose achievements are hardly ever discussed within the framework of the general history of astronomy. And yet the analysis of their activities allows for the complete reconstruction of $17^{\text {th }}$ century astronomy, including its diversification which stemmed from the tensions between tradition and modernity as well as from the specific research interests of minor scholars. One such case is Maria Cunitia (1610-1664) and her husband, Elias von Löwen (Crätschmair; c. 1602-1661) based in Silesia. Maria Cunitia is acknowledged for her Urania Propitia (1650), an innovative adaptation of the mathematical astronomy of Johannes Kepler's Rudolphine Tables. In turn von Löwen authored astronomical calendars and ephemerids. Their correspondence with Hevelius - 22 letters from the years 1648-1654 - constitutes an important source of knowledge about the astronomical 'background' which allowed them to complete their published works as well as about the activities of such astronomers from outside the major scientific centres. It is my intention to discuss the astronomical content of these letters.

Keywords: Johannes Hevelius, Maria Cunitia, Maria Cunitz, Elias von Löwen, Crätschmair, Johannes Kepler, astronomical tables, planetary conjunctions, libration of the Moon Słowa kluczowe: Jan Heweliusz, Maria Cunitia, Maria Cunitz, Elias von Löwen, Crätschmair, Johannes Kepler, tablice astronomiczne, koniunkcje planet, libracja Księżyca 
The correspondence of Johannes Hevelius comprises a compact set of 22 letters written in the years 1648-1654 and exchanged with Maria Cunitia and Elias von Löwen, known also as Crätschmair, a couple based in Silesia. ${ }^{1}$ These letters constitute a most interesting example of the exchange of ideas between, on the one hand, Hevelius - representing the mainstream astronomy of $17^{\text {th }}$ century Europe and based in the powerful scientific centre of Gdańsk, and, on the other hand, astronomers working on the peripheries of the then scientific Europe. In the following brief overview of the said correspondence I would like to demonstrate how researching these letters can significantly contribute to our knowledge about $17^{\text {th }}$ century astronomy and the dissemination of scientific ideas.

Maria Cunitia and Elias von Löwen appear for the first time in Hevelius's correspondence on 15 November 1646. Writing a reply to Marin Mersenne, who inquired about mathematicians working on Polish territories, Hevelius enumerates a new names: the late Peter Crüger (1580-1639) and Laurentius Eichstadt (1596-1660) from Gdańsk; Albertus Linemannus (1603-1653) from Königsberg; and "in Polonia": Frederik Getkant (16001666), Christian Otter (1598-1660) in Warsaw, and Jan Amos Komenský (1592-1670) in Leszno; and finally, Maria Cunitia in Silesia. Elias figures only as the husband of his wife, and the relevant passage reads as follows:

I've heard and believe that in the Silesian village of Łubnice, the wife of the physician Elias Crätschmair, Anna Cunicea, is compiling an extraordinary astronomical treaty which, perhaps, is already in print. The woman knows not only mathematics but also foreign languages, Greek and Latin in particular. ${ }^{2}$

Hevelius acknowledged that the information did not come directly from the source. This is further exemplified by the way he referred to Maria, confusing her name (Anna) and misspelling her surname, Cunicea. We do not know how he came across the information about the astronomical activities of Maria and what he knew about her as a person. The first information about the life of Maria Cunitia appeared in print as early as in 1650, in her work entitled Urania Propitia, and then in 1657, in a book written by Johannes Herbinius who knew her personally. Between these years, on 2 December 1651, Elias sent Hevelius a brief note on Maria. ${ }^{3}$

1 The alphabetical and chronological list of Hevelius's correspondence is to be found in: Correspondance de Johannes Hevelius. Tome I: Prolégomènes critiques, ed. by C. Grell, Turnhout 2014, pp. 247-561. The electronic repository of the scanned correspondence of Hevelius held in the Paris Observatory Library can be reached at: alidade.obspm.fr [accessed 24.02.2019].

2 Bibliothèque nationale de France [BnF], NAF 6206, 234-237 (124r-125r).

3 Cf. M. Cunitia, Urania Propitia, Oleśnica 1650; J. Herbinius, Dissertatio historica I, De foeminarum illustrium eruditione, Wittenberg 1657; von Löwen to Hevelius, Bibliothèque Observatoire de Paris [OBS], C1, v. 2, 260. The bibliographical information derived from extant sources are discussed in : K. Targosz, Sawantki w Polsce XVII w. Aspiracje intelektualne kobiet ze środowisk dworskich, Warszawa 1997, pp. 392-460; K. Liwowsky, Einige Neuigkeiten über die Familie der Schlesierin Maria Cunitz, $3^{\text {rd }}$ edition, Koblencja 2010. N.M. Swerdlow presents a comprehensive overview of recent publications on Cunitia in: Urania Propitia, Tabulae Rudolphinae faciles redditae a Maria Cunitia. Beneficent Urania, the Adaptation of the Rudolphine Tables by Maria Cunitz, [in:] A Master of Science History: Essays in Honor of Charles Coulston Gillispie, ed. by J.Z. Buchwald, Dordrecht 2012, pp. 81-121. Cf. also Astronom Maria Kunic (Cunitia) 1610-1664. Życie i dzieło, ed. by R. Skowron, Świdnica 2008. 


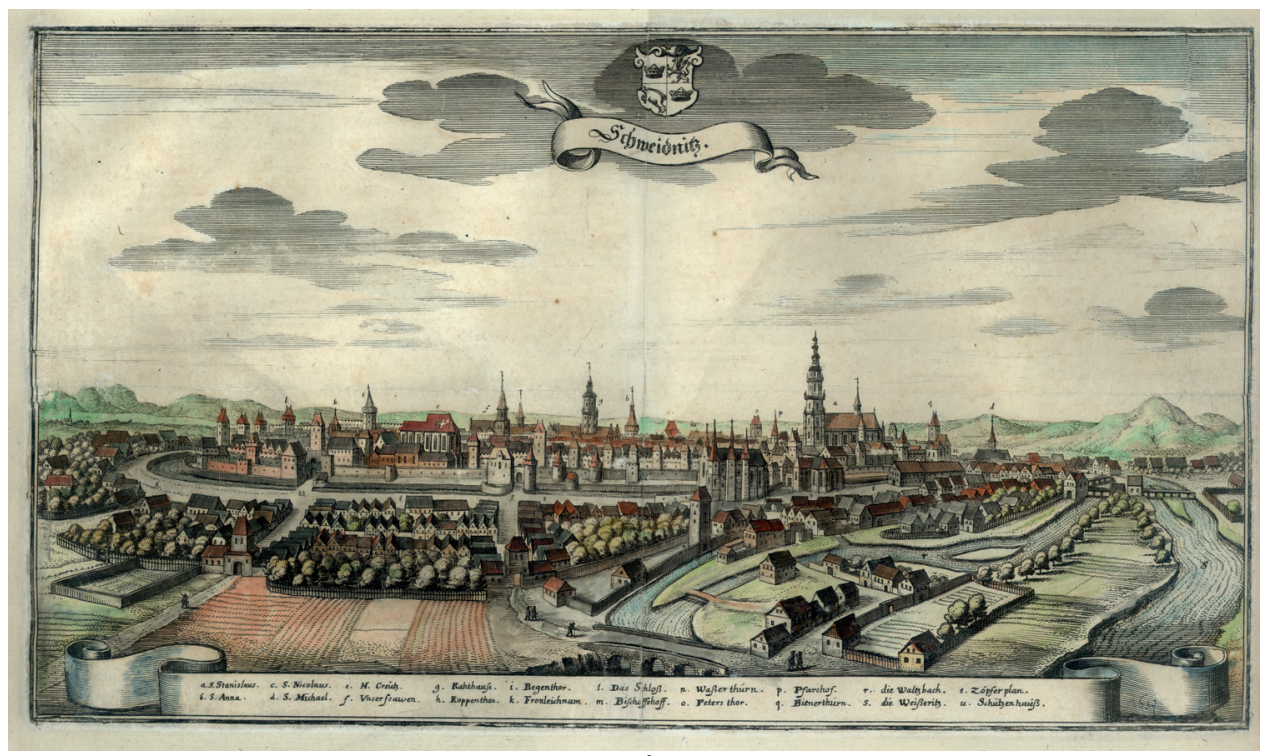

Figure 1. M. Merian, The panorama of Świdnica, c. 1650. M. Zeiller, Topographia Bohemiae, Moraviae et Silesiae, Frankfurt 1650. Courtesy of Muzeum Dawnego Kupiectwa, Świdnica.

Setting aside the biographical details, let us have a closer look at what is relevant today. Maria was born approximately in 1610, presumably in Świdnica. She never left Silesia, and she spent her whole adult life travelling between Świdnica, Łubnice and Byczyna (Pitschen), the largest distance separating one place from another being approximately $150 \mathrm{~km}$. She met Elias, her second husband, in 1625 when he moved to Świdnica. They married in 1630. At that time Elias was already a physician (he studied at the University in Franfkurt an der Oder) and the author of astrological almanacs. In 1636 or somewhat earlier due to the Thrity Years' War, they were forced to move into more peaceful Polish territories. They lived in Łubnice for almost twelve years, supported by the two successive prioresses of the Cistercian Cloister in Ołobok. Around 1650 they again crossed the PolishSilesian border and settled down in Elias's hometown, Byczyna, less than ten kilometres from Łubnice. In May 1655 a fire totally destroyed their house, as well as their astronomical notes and instruments.

The fact that Elias von Löwen compiled astrological almanacs was at that time a fairly typical pursuit for an educated and practicing physician. The biographies of Maria include accounts that she too was interested in horoscopes used for medical purposes and she could calculate them before she met Elias. If it were not for her gender, her skills could be seen as hardly unusual: Maria's father was a physician. However, the activities of Elias and Maria went far beyond the common business of compiling prognostications. The chronology of events seems to indicate that this extraordinary synergy was produced by the publication of two new astronomical works which coincided with the coming together of Maria and Elias.

Let as recall some facts. Elias moved to Świdnica around 1625, and he married Maria in 1630. Meantime, in 1622, a student of Tycho Brahe, Longomontanus published Astronomia Danica, with new astronomical tables. At the end of 1627 Johannes Kepler 


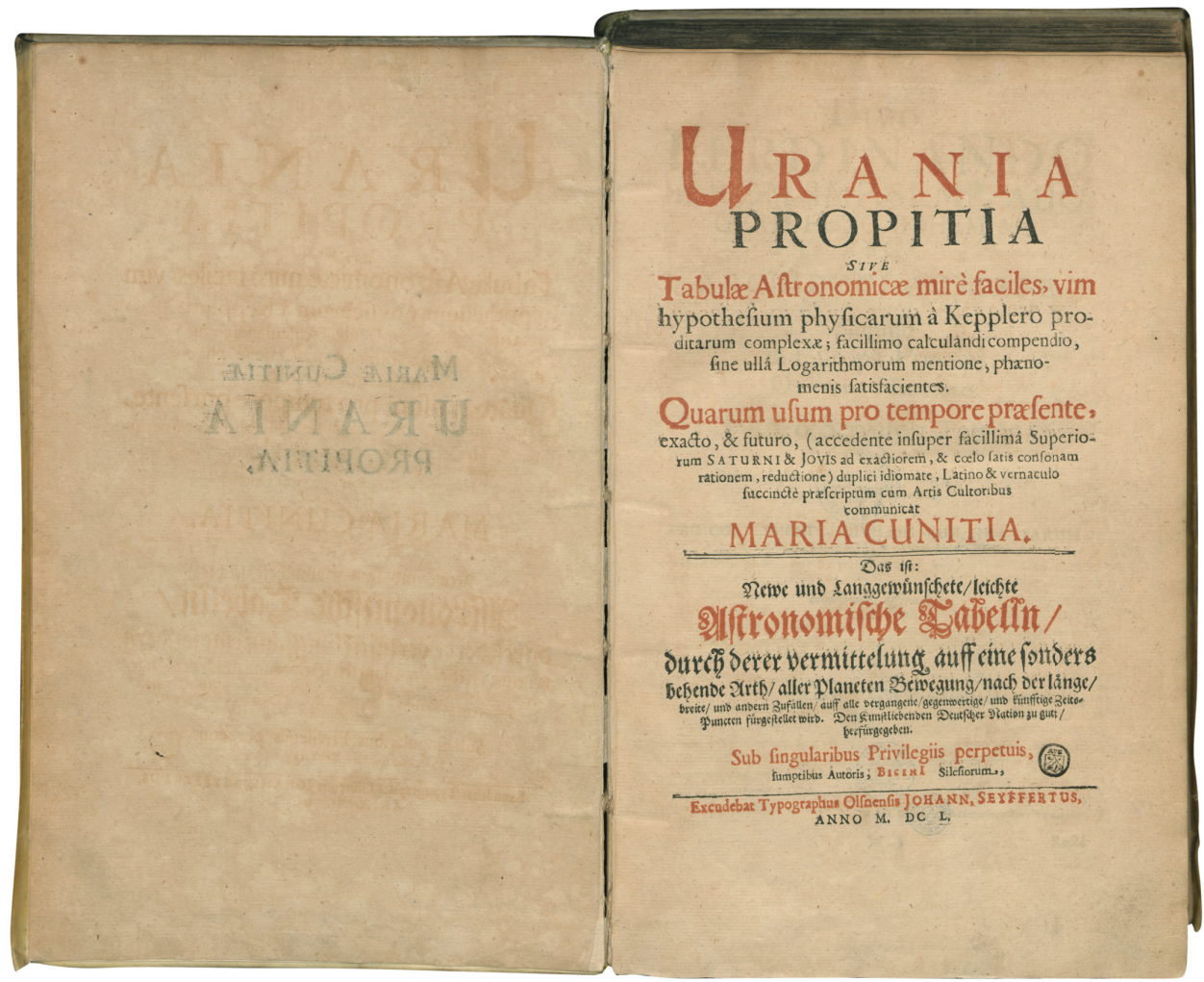

Figure 2. The title page of Cunitia's Urania Propitia. Courtesy of Wrocław University Library. Shelf mark 363158.

published the Rudolphine Tables based on his astronomy of the ellipses. Astronomical tables made it possible to calculate the positions of the planets. The results obtained on the basis of various tables could be compared, as well as checked against the apparent movement of the planets against the stars. Such observations, made in Świdnica in the years 1627-1629, were presented by Maria in her book Urania Propitia. These were three conjunctions of Saturn and Jupiter with the stars. The other two conjunctions described in Urania Propitia came from 1649, i.e. from the period shortly before the publication of the book. According to Elias and Maria, these observations confirmed beyond any doubt the superiority of the Rudolphine Tables over all other astronomical tables. To propagate Kepler's tables, Maria undertook to present them in a form which would facilitate calculations, but preserve their accuracy. This was the origin of Urania Propitia or Beneficent Urania as translated by Noel Swerdlow in his superb analysis of this work published six years ago. ${ }^{4}$

At this point let us put aside Cunitia's Beneficent Urania and see what kind of treasures can be found by a historian of science in the unpublished letters exchanged between Maria, Elias and Hevelius. Historians, such as Karolina Targosz $z^{5}$ and Ingrid 
Guentherodt, ${ }^{6}$ have already drawn our attention to three sets of problems: first, to the possibility of tracing additional biographical facts; secondly, to the possibility of broadening our knowledge about the vicissitudes of the printing history of scientific books; and thirdly, in this particular case, to the possibility of observing the reaction of the European scientific community to the emergence of a woman-scholar. However, I would like to offer yet another perspective.

First of all let us notice that one of the main, if not the major, astronomical topic of these letters are the observations, new methods and new instruments, and the telescope in particular. Here is a table juxtaposing the known observations of Elias and Maria, published in Urania Propitia, and the observations described in letters (Table 1). With the latter taken into account, the total number of observations increases twofold. But the difference is not only in numbers. All the observations in Urania Propitia are of the same kind and consist in determining the position of the planet and comparing the resulting coordinates with astronomical tables. Meantime, in the letters there are also other observations mentioned, i.e. solar eclipses and the optical libration of the Moon.

Table 1.

\begin{tabular}{|c|c|c|}
\hline \multicolumn{3}{|c|}{$\begin{array}{c}\text { "PERIPHERAL" ASTRONOMY: } \\
\text { ASTRONOMICAL OBSERVATIONS OF ELIAS VON LÖWEN AND MARIA CUNITIA }\end{array}$} \\
\hline $\begin{array}{l}\text { Published: } \\
\text { Urania propitia } 1650\end{array}$ & $\begin{array}{l}\text { Unpublished: } \\
\text { Date of } \\
\text { observation(s) } \\
\text { (date of the letter) }\end{array}$ & Remarks \\
\hline & 1623 (24 June 1650) & The optical libration of the Moon \\
\hline 26 Apr/6 May 1627 & & Jupiter and $\beta$ Sco / conjunction \\
\hline 4/14 Dec 1627 & & Saturn and 44 Vir / occultation / conjunction \\
\hline \multirow[t]{2}{*}{ 18/28 Oct 1629} & & Jupiter and $\gamma$ Cap / angular separation \\
\hline & $\begin{array}{l}\text { Feb-Apr } 1634 \\
\quad(28 \text { Feb 1648) }\end{array}$ & $\beta$ and $v$ Aur / ecliptic coordinates \\
\hline 1/11 May 1649 & & Jupiter and $\eta$ Vir / conjunction \\
\hline \multirow[t]{4}{*}{31 May/10 June 1649} & & Jupiter and $\eta$ Vir / conjunction \\
\hline & \begin{tabular}{|r|}
4 Nov 1649 \\
$\quad(2$ Dec 1651)
\end{tabular} & Solar eclipse \\
\hline & $\begin{array}{l}13 \text { Nov } 1650 \\
\quad(2 \text { Dec } 1651)\end{array}$ & Mars and $\sigma$ Leo / conjunction \\
\hline & $\begin{array}{l}13 \text { Aug } 1651 \\
\text { (2 Dec 1651) }\end{array}$ & Venus and Saturn / conjunction \\
\hline
\end{tabular}

In his letters Elias acknowledges that he systemically observes solar eclipses. In his letter from 24 January, 1650 he writes that camera obscura or a pinhole camera is far more suitable for such observations than a telescope because it does not distort the image. ${ }^{7}$

6 Cf. I. Guentherodt, Zum Briefwechsel des schlesischen Gelehrtenehepaars Cunitia / de Leonibus um 1650 mit den Astronomen Hevelius, Danzig und Bullialdus, Paris, [in:] Kommunikation in der Frühen Neuzeit, ed. by K.-D. Herbst and S. Kratochwil, Frankfurt 2009, pp. 171-188. This article also presents the results of Guentherodt's earlier studies on Cunitia.

7 OBS, C1, v. 2, 149. 
In a reply written three weeks later (12 February 1650). ${ }^{8}$ Hevelius observes that Elias is wrong. Kepler in his Optics (Astronomiae pars optica), published 40 years earlier, proved that such observations are imprecise and the error is due to the dimeter of the opening in camera obscura. ${ }^{9}$ This was rather a harsh lesson for Elias and Maria as propagators of Kepler's work.

The observations of the solar eclipses appear first in Elias's letters and then in the replies from Hevelius ${ }^{10}$ in a wider context of the discussion of the suitability of a new instrument, i.e. the telescope. ${ }^{11}$ Both invoke many different arguments. Interestingly enough, Elias seems to be more conservative, whereas Hevelius strongly underscores the benefits of the telescope, sometimes counter-arguing Elias's remarks. This is most interesting material, worth further analysis, especially if we remember that fifteen years later Rober Hooke will famously accuse Hevelius of being regressive in his choice of observational methods, and in particular of avoiding telescopes in certain types of astronomical measurements. ${ }^{12}$

Elias's letters also contain information about phenomena which have not yet been discussed by the historians of astronomy. Incidentally, these are also phenomena which I have recently studied in another context. In the letter from 28 February 1648, Elias describes his attempts at verifying the coordinates of the stars featuring in the catalogues of Tycho and Kepler. ${ }^{13}$ He presents the results of his own observations and concludes that they are different from the coordinates featuring in the catalogues.

Then he adds that he verified the coordinates of the stars he also measured against the positions of the planets calculated on the basis of astronomical tables. This is a surprising confession as in the whole history of ancient astronomy it was the stars which served as a point of reference for calculating the positions of planets. This shift testifies to the trust of the new generation of astronomers in the accuracy of new astronomical theories and new authority figures. So far I have come across such an approach only once. In 1572 Paul Wittich, a mathematician from Wrocław, observed Jupiter approximating a star, and used a theoretically predicted position of a planet (according to Copernican astronomy) to confirm the location of a star. He made a note about his observation on the margin of Copernicus's star catalogue in his copy of De revolutionibus. ${ }^{14}$ Elias's letter encourages us to further search for similar cases. They may constitute an interesting and so far unacknowledged aspect of the early reception of heliocentric theory.

8 OBS, C1, v. 2, 151.

9 Cf. i.e. S. Straker, Kepler, Tycho, and the 'Optical part of astronomy': the genesis of Kepler's theory of pinhole images, "Archive for history of exact sciences" vol. 24, 1981, pp. 267-293.

10 Von Löwen to Hevelius, 2.12.1651, OBS, C1, v. 2, 260; Hevelius to von Löwen, 18.05.1652, OBS, C1, v. 2, 261; 29.07.1652, OBS, v. 2, 297; von Löwen to Hevelius, 22.03.1653, OBS, C1, v. 3, 380; 28.07.1653, OBS, C1, v. 3, 383; Hevelius to von Löwen, 10.04.1654, OBS, C1, v. 3, 385.

11 Von Löwen to Hevelius, 28.02.1648, OBS, C1, v. 1, 113/224/113; 24.01.1650, OBS, C1, v. 2, 149; Hevelius to von Löwen, 12.02.1650, OBS, C1, v. 2, 151; von Löwen to Hevelius, 24.06.1650, OBS, C1, v. 2, 190 + v. 1, 190T.

12 Cf. i.e. V. Saridakis, The Hevelius - Hooke Controversy in Context: Transforming Astronomical Practice in the Late Seventeenth Century, [in:] Johannes Hevelius and His World: Astronomer, Cartographer, Philosopher and Correspondent, ed. by R.L. Kremer and J. Włodarczyk, Warszawa 2013 (Studia Copernicana, vol. XLIV), pp. 103-135.

13 OBS, C1, v. 1, 113/224/113.

14 J. Włodarczyk, R.L. Kremer, H.C. Hughes, Edward Gresham, Copernican Cosmology, and Planetary Occultations in Pre-Telescopic Astronomy, "Journal for the History of Astronomy" vol. 49, 2018, pp. 269-305. 
The fourth example showing the great value of the correspondence of Elias, Maria and Hevelius for the history of astronomy are the passages which refer to the optical libration of the Moon. This case has no precedence whatsoever.

The optical libration of the Moon refers to the phenomenon when lunar spots visible on the face of the Moon change their position relative to the edges of the lunar disk. Its discovery was strictly tied to the development of telescopic observations of the Moon's surface in the first half of the $17^{\text {th }}$ century, as well as to the emergence of selenography, a new discipline in the field of celestial cartography. The first published references to this phenomenon are said to be found in the works of the Dutchman Michael van Langren, Royal Cosmographer and Mathematician to King Philip IV of Spain, and Galileo Galilei. Both originate in the 1630s. However, the first relatively complete description of lunar libration was published by Hevelius in his Selenographia in 1647, a year before he started his correspondence with Elias and Maria. ${ }^{15}$

Meantime, in his letter of 24 June 1650, Elias, having read Hevelius's book about the Moon, states that first of all, he observed the libration of the Moon much earlier, and, secondly, that he already identified "its reasons" in $1623 .{ }^{16}$ To support his claim to be first to discover it, Elias attached to his letter his prognostications as regards the libration of the Moon in the second half of 1650. So far I have not been able assess what the relation of Elias's prognostications to Hevelius's work is and to the actual appearance of the Moon at that time. However, we can already risk the hypothesis that this part of the correspondence of Hevelius breathes some new life into the history of astronomy and into the history of selenography in particular.

In conclusion, there are a surprising number of truly significant benefits for the history of astronomy from reading the rather scarce correspondence of Elias von Löwen, Maria Cunitia and Johannes Hevelius.

Their letters allow us to supplement the set of published astronomical observations with some hitherto unknown observations and discoveries. Surprisingly, this sometimes casts new light on the chronology of discoveries, as in the case of the optical libration of the Moon.

The letters are a new source of knowledge about the assessment of observational methods by minor astronomers in the first half of the $17^{\text {th }}$ century (e.g. camera obscura) and the arguments they used in the discussion of the usefulness of new instruments such as the telescope.

The letters also open a new vista of research as regards the early reception of new theories of the movement of planets. This refers in particular to the hitherto undocumented revered relation between calculating the positions of the planets and stars. i.e. when theoretically computed positions of planets serve to verify the accuracy of star catalogues.

One can also mention some other interesting topics resurfacing in these few letters, such as, for example, the methods of coming into the possession of telescopes in the first half of the $17^{\text {th }}$ century, the dissemination of instruments, or the vicissitudes of the printing history of scientific books. 
All these fascinating aspects of the correspondence of Elias and Maria and Hevelius now require a detailed analysis and placing them carefully against the background of other known facts about the history of astronomy. They are also bound to be extensively discussed in the commentaries featuring in the upcoming critical edition of the said letters.

\section{Bibliography}

\section{Manuscript sources}

Bibliothèque d'Observatoire de Paris, Correspondance de Johannes Hevelius, C1, v. 1-3. Bibliothèque nationale de France (BnF), NAF 6206, 234-237 (124r-125r).

\section{Printed sources}

Cunitia M., Urania Propitia, Oleśnica 1650.

Herbinius J., Dissertatio historica I, De foeminarum illustrium erudition, Wittenberg 1657.

\section{Critical literature}

Astronom Maria Kunic (Cunitia) 1610-1664. Życie i dzieło, ed. by R. Skowron, Świdnica 2008.

Correspondance de Johannes Hevelius. Tome I: Prolégomènes critiques, ed. by C. Grell, Turnhout 2014.

Guentherodt I., Zum Briefwechsel des schlesischen Gelehrtenehepaars Cunitia / de Leonibus um 1650 mit den Astronomen Hevelius, Danzig und Bullialdus, Paris, [in:] Kommunikation in der Frühen Neuzeit, ed. by K.-D. Herbst and S. Kratochwil, Frankfurt 2009, pp. 171-188.

Liwowsky K., Einige Neuigkeiten über die Familie der Schlesierin Maria Cunitz, $3^{\text {rd }}$ edition, Koblencja 2010.

Saridakis V., The Hevelius - Hooke Controversy in Context: Transfroming Astronomical Practice in the Late Seventeenth Century, [in:] Johannes Hevelius and His World: Astronomer, Cartographer, Philosopher and Correspondent, ed. by R.L. Kremer and J. Włodarczyk, Warszawa 2013 (Studia Copernicana, vol. XLIV), pp. 103-135.

Straker S., Kepler, Tycho, and the 'Optical part of astronomy': the genesis of Kepler's theory of pinhole images, "Archive for history of exact sciences" vol. 24, 1981, pp. 267-293.

Swerdlow N.M., Urania Propitia, Tabulae Rudolphinae faciles redditae a Maria Cunitia. Beneficent Urania, the Adaptation of the Rudolphine Tables by Maria Cunitz, [in:] A Master of Science History: Essays in Honor of Charles Coulston Gillispie, ed. by J.Z. Buchwald, Dordrecht 2012, pp. 81-121.

Targosz K., Sawantki w Polsce XVII w. Aspiracje intelektualne kobiet ze środowisk dworskich, Warszawa 1997.

Włodarczyk J., Libration of the Moon, Hevelius's Theory, and Its Early Reception in England, "Journal for the History of Astronomy" vol. 42, 2011, pp. 495-519.

Włodarczyk J., Kremer R.L., Hughes H.C., Edward Gresham, Copernican Cosmology, and Planetary Occultations in Pre-Telescopic Astronomy, "Journal for the History of Astronomy" vol. 49, 2018, pp. 269-305. 
JAROSŁAW WŁODARCZYK is a Professor at the Institute for the History of Science, Polish Academy of Sciences, Warsaw. His research focuses on the history of observational astronomy, the relation between observations and astronomical theories, and the cultural context(s) of astronomy. He is currently taking part in a collaborative project on the correspondence of Johannes Hevelius. E-mail: jaroslawwlodarczyk@wp.pl

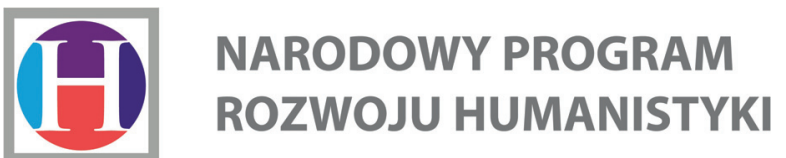

Praca naukowa finansowana w ramach programu Ministra Nauki i Szkolnictwa Wyższego pod nazwą "Narodowy Program Rozwoju Humanistyki” w latach 2015-2018 